\title{
METHOD OF NUMERICAL ANALYSIS OF THE PROBLEM OF STATIONARY FLOW PAST BODIES OF REVOLUTION BY VISCOUS FLUID
}

Context. The nonlinear stations problem of flow past a body of revolution by a viscous incompressible fluid is examined in this article.

Objective. The purpose of this work is to develop a new method of numerical analysis of stationary problems of flow around bodies of revolution by viscous incompressible fluid.

Method. The mathematical model of the process under consideration is a nonlinear boundary value problem for the stream function obtained by the transition from the system of Navier-Stokes equations to one nonlinear equation of the fourth order. A special feature of the formulation the task of the flow past body is that the boundary value problem is considered in an infinite region and both boundary conditions on the boundary of the streamlined body and the condition at infinity are imposed for the stream function. Using the structural method (the $R$-functions method), the task solution structure, that exactly satisfies all the boundary conditions of the task, and also guarantees the necessary behavior of the stream function at infinity, is constructed. Two approaches are proposed to approximate the uncertain components of the structure. The first approach is based on the use of the successive approximations method, which makes it possible to reduce the solution of the initial nonlinear task to the solution of a sequence of linear boundary value problems. These linear tasks are solved by the BubnovGalerkin method at each step of the iteration process. The second approach for approximating the uncertain components of the structure is based on the usage of the nonlinear Galerkin method and it is proposed to use it in the case of divergence of successive approximations. In this case, the solution of the initial nonlinear task reduces to solving a system of nonlinear algebraic equations.

Results. A computational experiment was carried out for the task of flow past a sphere, an ellipsoid of rotation and two articulated ellipsoids for various Reynolds numbers.

Conclusions. The conducted experiments have confirmed the efficiency of the proposed method of numerical analysis of stationary problems of flow around bodies of revolution by viscous incompressible fluid. The prospects for further research may consist in using the method developed for the implementation of semi-discrete and projection methods for solving non-stationary problems.

Keywords: flow past bodies, stationary flow, viscous fluid, stream function, $R$-functions method, successive approximations method, Galerkin method.

\section{NOMENCLATURE}

$\partial \Omega$ - boundary of a streamlined body;

$E$ - Stokes operator in a spherical coordinate system;

$F$ - class of functions which have generalized derivatives up to the second order inclusive and are quadratically summable together with the derivatives with respect to $\Omega_{1}$; on the boundary $\partial \Omega$ they meet to the homogeneous boundary conditions of the corresponding task;

$J_{n}(\zeta)$ - Gegenbauer functions of the first kind;

n - outer normal to $\partial \Omega$;

$r, \theta, \varphi$ - variables of the spherical coordinate system;

$\mathrm{Re}-$ Reynolds number;

$u$ - solution of the auxiliary task with homogeneous boundary conditions;

$u_{n}^{(0)}, \quad, u_{n}^{(k)}, \ldots-$ sequence of approximations to the generalized solution of the task for $u$, which is considered in the finite domain;

$u_{n}^{*}-$ generalized solution of the task for $u$, which is considered in the finite domain;
$U_{\infty}$ - unperturbed fluid velocity at infinity;

$v=\mathrm{Re}^{-1}-$ viscosity factor;

$\left\{\varphi_{k}(r, \theta)\right\}-$ a complete system of particular solutions of the equation $E^{2} u=0$ with respect to the exterior of a sphere of finite radius;

$\left\{\tau_{j}(r, \theta)\right\}-$ a complete system of particular solutions of the equation $E^{2} u=0$ relative to the domain $\{\omega(r, \theta)<M\}$;

$\left\{\phi_{i}(r, \theta)\right\}$ - sequence of functions that is complete concerning whole plane;

$\Phi_{1}, \Phi_{2}-$ undefined components of the solution structure;

$\psi=\psi(r, \theta)-$ stream function;

$\omega$ - a sufficiently smooth function, built with the help of a constructive apparatus of the $R$-functions theory;

$\omega=0$ - normalized equation of $\partial \Omega$;

$\Omega$ - flow domain;

$\Omega_{n}$ - bounded domain $\left\{0<\omega(r, \theta)<M_{n}\right\}$;

$\Omega_{1}$ - any finite part of $\Omega$. 


\section{INTRODUCTION}

The phenomena, which are observed in the atmosphere and the hydrosphere, the problems of hydrodynamics, aerodynamics, heat power engineering, chemical kinetics, and biomedicine, can be often researched within the framework of an incompressible viscous fluid model. The tasks, which represent the practical interest, as a rule, are described by the nonlinear Navier-Stokes equations. In the case, when the task possesses symmetry properties and can be reduced to a two-dimensional one, it is convenient to enter the stream function instead of components of the fluid velocity. Methods for solving the external tasks (problems of flow past bodies) for equations with respect to the stream function have not been developed sufficiently, which is due to the high order and nonlinearity of the equations, as well as the limitlessness of the domain in which the equations are considered. The structural $R$-functions method, which has been used in this work, allows to construct the so-called structures of the solution of boundary value problems are bundles of functions which exactly satisfy all the boundary conditions of the task. The geometry of the area is taken into account exactly. Approximating further the undefined components of the solution structure by some projection method, we obtain an approximate solution in an analytical form, which facilitates its further usage for finding various flow characteristics. Thus, the development of new, as well as the improvement of existing methods of mathematical modeling of stationary problems of flow past bodies by viscous incompressible fluid using the $R$-function method, is a scientific issue of current interest.

The object of the investigation is the stationary hydrodynamic process of flow past bodies by a viscous incompressible fluid, described by a nonlinear equation with respect to the stream function.

The subject of the study is a mathematical model of the stationary problem of flow past a body by viscous incompressible fluid and the method of its numerical analysis.

The purpose of the work is to develop a new method of mathematical simulation of stationary flow past bodies of revolution by viscous incompressible fluid on the basis of the $R$-function method.

\section{PROBLEM STATEMENT}

We consider the nonlinear steady-state problem of flow past body of rotation by viscous incompressible fluid in a spherical coordinate system $[1,2]$ :

$$
\begin{gathered}
v E^{2} \psi=\frac{1}{r^{2} \sin \theta}\left(\frac{\partial \psi}{\partial \theta} \frac{\partial E \psi}{\partial r}-\frac{\partial \psi}{\partial r} \frac{\partial E \psi}{\partial \theta}\right)+ \\
+\frac{1}{r^{2} \sin \theta}\left(2 \operatorname{ctg} \theta \frac{\partial \psi}{\partial r}-\frac{2}{r} \frac{\partial \psi}{\partial \theta}\right) E \psi \text { in } \Omega, \\
\left.\psi\right|_{\partial \Omega}=0,\left.\frac{\partial \psi}{\partial \mathbf{n}}\right|_{\partial \Omega}=0 \\
\lim _{r \rightarrow+\infty} \psi \cdot r^{-2}=\frac{1}{2} U_{\infty} \sin ^{2} \theta
\end{gathered}
$$

where $E \psi=\frac{\partial^{2} \psi}{\partial r^{2}}+\frac{\sin \theta}{r^{2}} \frac{\partial}{\partial \theta}\left(\frac{1}{\sin \theta} \frac{\partial \psi}{\partial \theta}\right)$.

\section{REVIEW OF THE LITERATURE}

In general, the methods of finite differences and finite elements are used for numerical analysis of hydrodynamic problems. The main advantage of these methods is the relative simplicity of implementation, however, when moving to a new domain (especially complex geometry), it is necessary to generate again and adjust the calculated grid under the task. Furthermore, the demolition of the conditions on infinity on a certain contour, which is located at a finite distance from the streamlined body, gives the additional errors in the approximate solution. Using the $R$ functions method [3, 4] of V. L. Rvachev, the Academician of Ukrainian National Academy of Sciences, it is possible to take precisely into account the geometric and analytical information included in the statement of the problem.

The $R$-functions method in hydrodynamics problems was used in [5-10], but the tasks for calculating steady flows of an ideal fluid, stationary and nonstationary flows of a viscous fluid in limited domains or viscous liquids in the presence of helical symmetry were considered. The tasks of flow past bodies of rotation by a stationary flow of a viscous fluid using the $R$-function method were solved in [11-16]. The task of calculating the external slow flow past bodies by a viscous incompressible fluid (Stokes linearization) is solved in [11-13]. Usage of $R$-functions method, successive approximations and Galerkin-Petrov method to calculate axisymmetric stationary flows of a viscous incompressible fluid was proposed in works $[14,15]$. The task of mass transfer of a body of rotation with a uniform translational flow was considered in [16].

In this work the $R$-functions method, successive approximations and Galerkin method are proposed to apply for mathematical modeling of nonlinear stationary task of flow past body of revolution by a viscous incompressible fluid.

\section{MATERIALS AND METHODS} [9]

For solving the task (1)-(3), we introduce the function

$$
f_{M}(x)=\left\{\begin{array}{l}
1-\exp \frac{M x}{x-M}, 0 \leq x<M ; \\
1, x \geq M \quad(M=\text { const }>0),
\end{array}\right.
$$

which meets the following conditions:

$$
\text { 1) } \omega_{M}>0 \text { in } \Omega \text {;2) }\left.\omega_{M}\right|_{\partial \Omega}=0 \text {; }
$$

$$
\text { 3) }\left.\frac{\partial \omega_{M}}{\partial \mathbf{n}}\right|_{\partial \Omega}=-1 \text {; 4) } \omega_{M} \equiv 1 \text {, if } \omega_{M} \geq M \text {. }
$$

In the task (1)-(3) we will make a replacement $\psi=u_{0}+u$, where $u_{0}$ is solution of the linear task (Stokes approximation):

$$
E^{2} u_{0}=0 \text { in } \Omega,
$$




$$
\begin{aligned}
& \left.u_{0}\right|_{\partial \Omega}=0,\left.\frac{\partial u_{0}}{\partial \mathbf{n}}\right|_{\partial \Omega}=0, \\
& \lim _{r \rightarrow+\infty} r^{-2} u_{0}=\frac{1}{2} U_{\infty} \sin ^{2} \theta .
\end{aligned}
$$

Method for solving the task (4)-(6) was developed in the works [11-13].

For function $u$ we obtain a boundary value problem with homogeneous boundary conditions

$$
\begin{gathered}
v E^{2} u=\frac{1}{r^{2} \sin \theta}\left(\frac{\partial\left(u_{0}+u\right)}{\partial \theta} \frac{\partial E\left(u_{0}+u\right)}{\partial r}-\right. \\
\left.-\frac{\partial\left(u_{0}+u\right)}{\partial r} \frac{\partial E\left(u_{0}+u\right)}{\partial \theta}\right)+\frac{1}{r^{2} \sin \theta}\left(2 \operatorname{ctg} \theta \frac{\partial\left(u_{0}+u\right)}{\partial r}-\right. \\
\left.-\frac{2}{r} \frac{\partial\left(u_{0}+u\right)}{\partial \theta}\right) E\left(u_{0}+u\right) \text { in } \Omega \\
\left.u\right|_{\partial \Omega}=0,\left.\frac{\partial u}{\partial \mathbf{n}}\right|_{\partial \Omega}=0 \\
\lim _{r \rightarrow+\infty} r^{-2} u=0
\end{gathered}
$$

We use the method of successive approximations to solve task (7)-(9). If the initial approximation is given $u_{n}^{(0)}$ and $k$ approximation $u_{n}^{(k)}$ is built, then the new $(k+1)$ approximation $u_{n}^{(k+1)}$ will be found as a solution of the linear problem

$$
\begin{aligned}
& v E^{2} u_{n}^{(k+1)}=\frac{1}{r^{2} \sin \theta}\left(\frac{\partial\left(u_{0}+u_{n}^{(k)}\right)}{\partial \theta} \frac{\partial E\left(u_{0}+u_{n}^{(k)}\right)}{\partial r}-\right. \\
&\left.-\frac{\partial\left(u_{0}+u_{n}^{(k)}\right)}{\partial r} \frac{\partial E\left(u_{0}+u_{n}^{(k)}\right)}{\partial \theta}\right)+ \\
&+\frac{1}{r^{2} \sin \theta}\left(2 \operatorname{ctg} \theta \frac{\partial\left(u_{0}+u_{n}^{(k)}\right)}{\partial r}-\right. \\
&-\frac{2}{r}\left.\frac{\partial\left(u_{0}+u_{n}^{(k)}\right)}{\partial \theta}\right) E\left(u_{0}+u_{n}^{(k)}\right) \text { in } \Omega_{n} \\
&\left.u_{n}^{(k+1)}\right|_{\partial \Omega}=0,\left.\frac{\partial u_{n}^{(k+1)}}{\partial \mathbf{n}}\right|_{\partial \Omega}=0
\end{aligned}
$$

continued by zero outside $\Omega_{n}$.

A theorem on the convergence of successive approximations (10)-(11) at small Reynolds numbers for each $n$ in the energy norm to a unique generalized solution $u_{n}^{*} \in F$ of the task (7)-(9), which is examined in a bounded domain $\Omega_{n}$, was formulated and proved in work [15].

According to the Bubnov-Galerkin method, at each iteration in the domain $\Omega_{n}$, we will seek the approximate solution of task (10)-(11) in the form

$$
u_{n, N}^{(k+1)}=\sum_{j=1}^{N} c_{n, j}^{(k+1)} \phi_{j}
$$

Numbers $c_{n, j}^{(k+1)}, j=1, \ldots, N$, are solution of the system of linear algebraic equations

$$
\sum_{j=1}^{N} c_{n, j}^{(k+1)} v\left(\left[\phi_{j}, \phi_{i}\right]+\left(K \phi_{j}, \phi_{i}\right)\right)=\left(f^{(k+1)}, \phi_{i}\right), i=\overline{1, N},
$$

where

$$
\begin{gathered}
K=-\Delta\left(\frac{2 \operatorname{ctg} \theta}{r^{2}} \frac{\partial}{\partial \theta}+\frac{2}{r} \frac{\partial}{\partial r}\right)- \\
-\left(\frac{2 \operatorname{ctg} \theta}{r^{2}} \frac{\partial}{\partial \theta}+\frac{2}{r} \frac{\partial}{\partial r}\right)\left(\Delta-\frac{2 \operatorname{ctg} \theta}{r^{2}} \frac{\partial}{\partial \theta}-\frac{2}{r} \frac{\partial}{\partial r}\right) \\
\left(f^{(k+1)}, \phi_{i}\right)=\int_{\Omega_{n}} E\left(u_{0}+u_{n}^{(k)}\right) \frac{\partial\left(u_{0}+u_{n}^{(k)}\right)}{\partial r} \frac{\partial \phi_{i}}{\partial \theta} d r d \theta- \\
-\int_{\Omega_{n}} E\left(u_{0}+u_{n}^{(k)}\right) \frac{\partial\left(u_{0}+u_{n}^{(k)}\right)}{\partial \theta} \frac{\partial \phi_{i}}{\partial r} d r d \theta+ \\
+\int_{\Omega_{n}} 2 \operatorname{ctg} \theta \frac{\partial\left(u_{0}+u_{n}^{(k)}\right)}{\partial r} E\left(u_{0}+u_{n}^{(k)}\right) \phi_{i} d r d \theta- \\
-\int_{\Omega_{n}} \frac{2}{r} \frac{\partial\left(u_{0}+u_{n}^{(k)}\right)}{\partial \theta} E\left(u_{0}+u_{n}^{(k)}\right) \phi_{i} d r d \theta
\end{gathered}
$$

We construct a system of coordinate functions $\left\{\phi_{i}\right\}$. For this we use a complete system of particular solutions of the equation $E^{2} u=0$ [17] and the structure method of $R$-functions [3, 4].

In work [13] it was proved that the function of the form

$$
u=\omega_{M}^{2} \Phi_{1}+\omega_{M}^{2}\left(1-\omega_{M}\right) \Phi_{2} .
$$

is the structure of the solution of the boundary value task (7)-(9), i.e. for any choice of sufficiently smooth functions $\Phi_{1}$ and $\Phi_{2}\left(\Phi_{1} \cdot r^{-2} \rightarrow 0\right.$ at $\left.r \rightarrow+\infty\right)$ it exactly satisfies the boundary conditions (8) and the condition at infinity (9).

Approximations of the indeterminate components $\Phi_{1}$ and $\Phi_{2}$ of structure (13) will be sought in the form

$$
\Phi_{1} \approx \Phi_{1}^{m_{1}}=\sum_{k=1}^{m_{1}} \alpha_{k} \cdot \varphi_{k}, \Phi_{2} \approx \Phi_{2}^{m_{2}}=\sum_{j=1}^{m_{2}} \beta_{j} \cdot \tau_{j},
$$


where

$$
\begin{gathered}
\left\{\varphi_{k}(r, \theta)\right\}=\left\{r^{1-k} J_{k}(\cos \theta), k=2,3, \ldots ;\right. \\
\left.r^{3-k} J_{k}(\cos \theta), k=4,5, \ldots\right\}, \\
\left\{\tau_{j}(r, \theta)\right\}=\left\{r J_{2}(\cos \theta), J_{3}(\cos \theta),\right. \\
\left.r^{j} J_{j}(\cos \theta), r^{j+2} J_{j}(\cos \theta), j=2,3, \ldots\right\} .
\end{gathered}
$$

Then, the complete sequence of functions concerning whole plane has the form:

$$
\begin{gathered}
\left\{\phi_{i}(r, \theta)\right\}=\left\{\omega_{M}^{2}(r, \theta) \varphi_{k}(r, \theta),\right. \\
\left.\omega_{M}^{2}(r, \theta)\left(1-\omega_{M}(r, \theta)\right) \tau_{j}(r, \theta)\right\} .
\end{gathered}
$$

In case of divergence of successive approximations we will use nonlinear Galerkin method. An approximate solution $u_{n, N}$ of the task (7)-(9) which is considered in the finite domain $\Omega_{n}$ is sought in the form (12). As a result, we obtain a system of nonlinear equations, each of which is a quadratic function with respect to $c_{n, j}$. As the initial approximation, we choose a set $c_{n, j}$, which corresponding to the solution of the linear task (Stokes approximation), or, for large Reynolds numbers, to the solution which obtained for smaller Reynolds numbers.

\section{EXPERIMENTS}

A computational experiment was carried out for the tasks of flow past a sphere, ellipsoids of rotation with different semi-axes, and two articulated ellipsoids. The double integrals in the systems for the determination $c_{n, j}$ were calculated approximately by the Gauss' formula with 50 nodes for each variable. For the method of successive approximations, calculations were ceased at $\varepsilon=10^{-6}$. It was experimentally established that for $\operatorname{Re}>10$ the successive approximations diverge. In this case, the nonlinear Galerkin method was used to obtain the approximate solution.

Calculations for the tasks of flow past a sphere $x^{2}+y^{2}+z^{2}=1$ at $U_{\infty}=1, M=10, m_{1}=10, m_{2}=14$, $\operatorname{Re}=10 ; 20 ; 25$, ellipsoid of revolution $\frac{x^{2}+y^{2}}{1,5^{2}}+z^{2}=1$ at $U_{\infty}=1, M=10, m_{1}=10, m_{2}=14, \operatorname{Re}=10 ; 30 ; 50$, two articulated ellipsoids, limited by surfaces $\frac{(x-1)^{2}+y^{2}}{2^{2}}+z^{2}=1, \frac{(x+1)^{2}+y^{2}}{2^{2}}+z^{2}=1$, at $U_{\infty}=1$, $M=10, \quad m_{1}=6, \quad m_{2}=10, \quad \operatorname{Re}=5 ; 10 ; 20, \quad$ were performed.

\section{RESULTS}

Fig. 1 shows the streamlined contours of the obtained approximate solution for the task of flow past a sphere. The detailed pictures of streamlined contours and vector velocity field behind the sphere are shown in Fig. 2.

Fig. 3 shows the streamlined contours of the obtained approximate solution for the task of flow past an ellipsoid of rotation. The detailed pictures of streamlined contours and vector velocity field behind the ellipsoid are shown in Fig. 4.

Fig. 5 shows the streamlined contours of the obtained approximate solution for the task of flow past two articulated ellipsoids. The detailed pictures of streamlined contours and vector velocity field behind ellipsoids and in the hollow between them are shown in Fig. 6 .
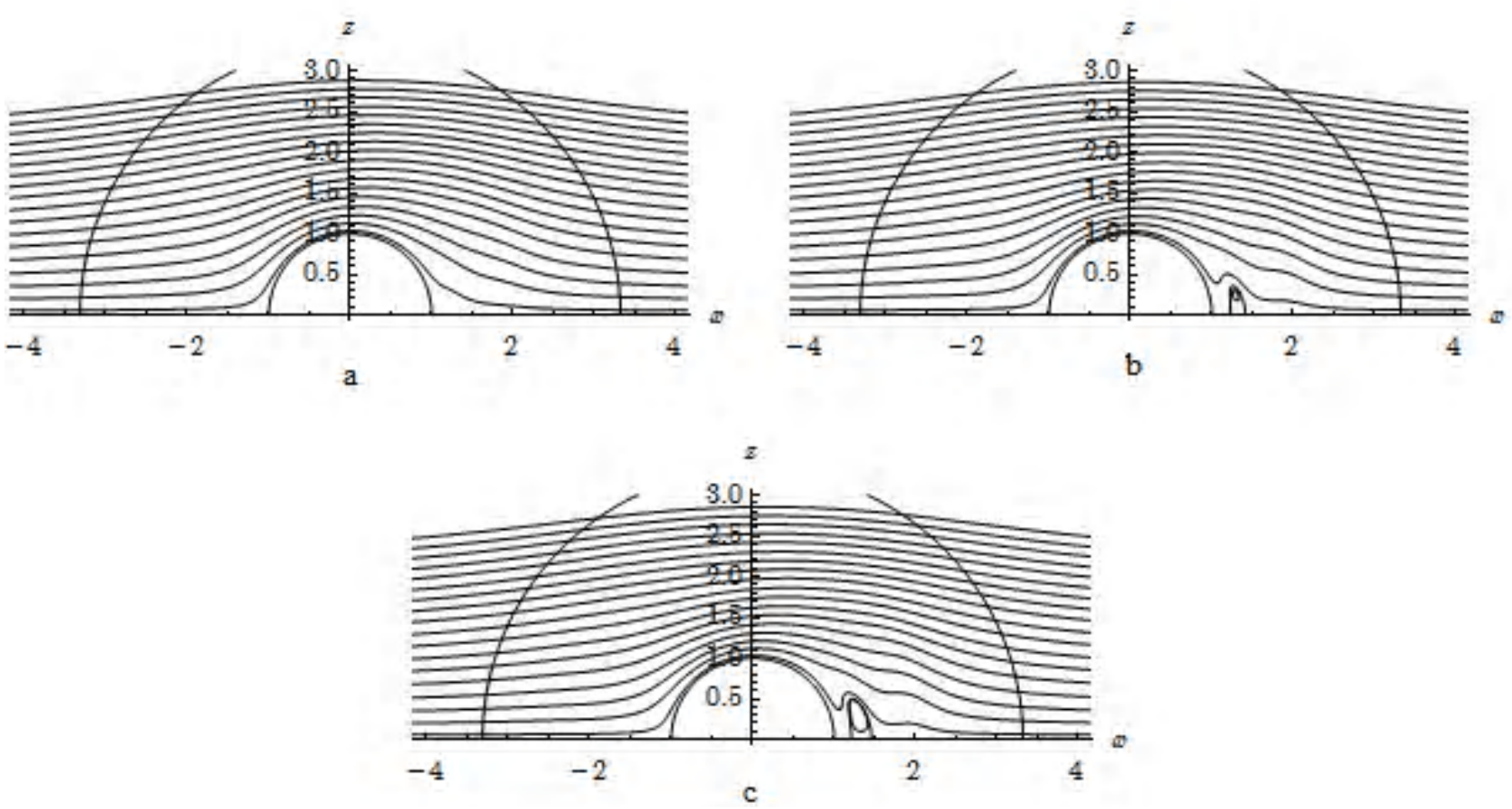

Figure 1 - Streamlined contours of obtained approximate solution for flow past a sphere:

$$
\mathrm{a}-\operatorname{Re}=10, \mathrm{~b}-\operatorname{Re}=20, \mathrm{c}-\operatorname{Re}=25
$$



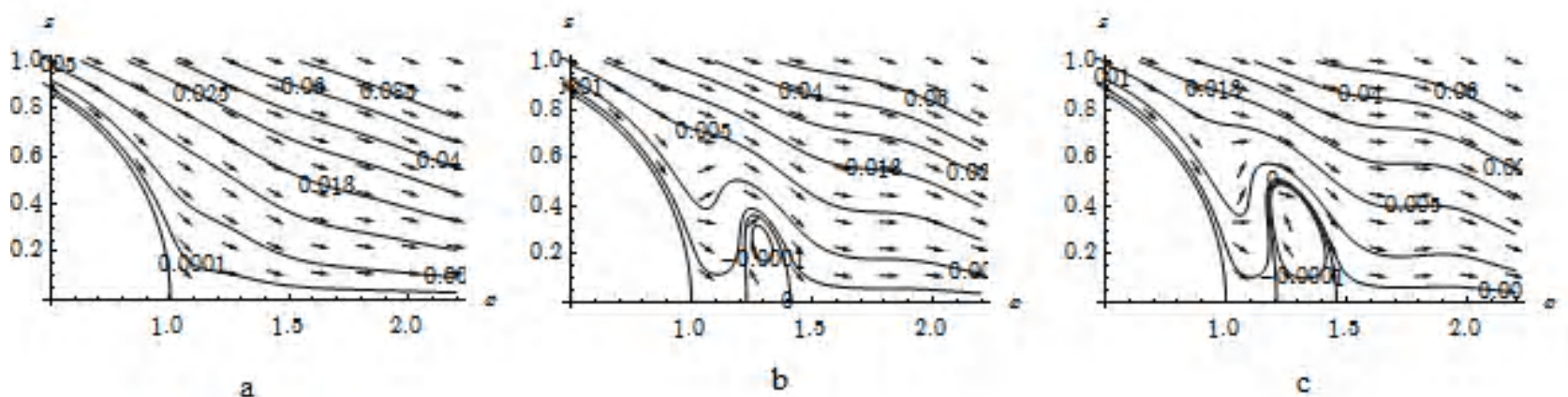

Figure 2 - Detailed pictures of streamlined contours and vector velocity field behind the sphere: $\mathrm{a}-\operatorname{Re}=10, \mathrm{~b}-\operatorname{Re}=20, \mathrm{c}-\operatorname{Re}=25$
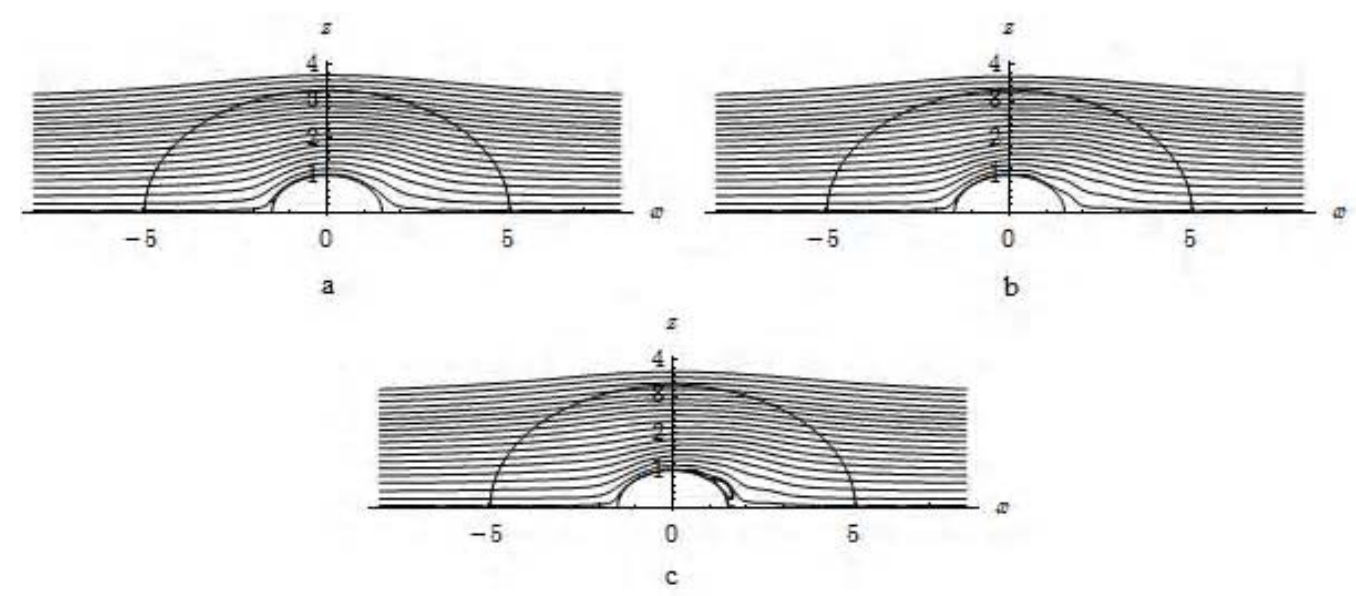

Figure 3 - Streamlined contours of obtained approximate solution for flow past an ellipsoid of rotation:

$$
\mathrm{a}-\operatorname{Re}=10, \mathrm{~b}-\operatorname{Re}=30, \mathrm{c}-\operatorname{Re}=50
$$
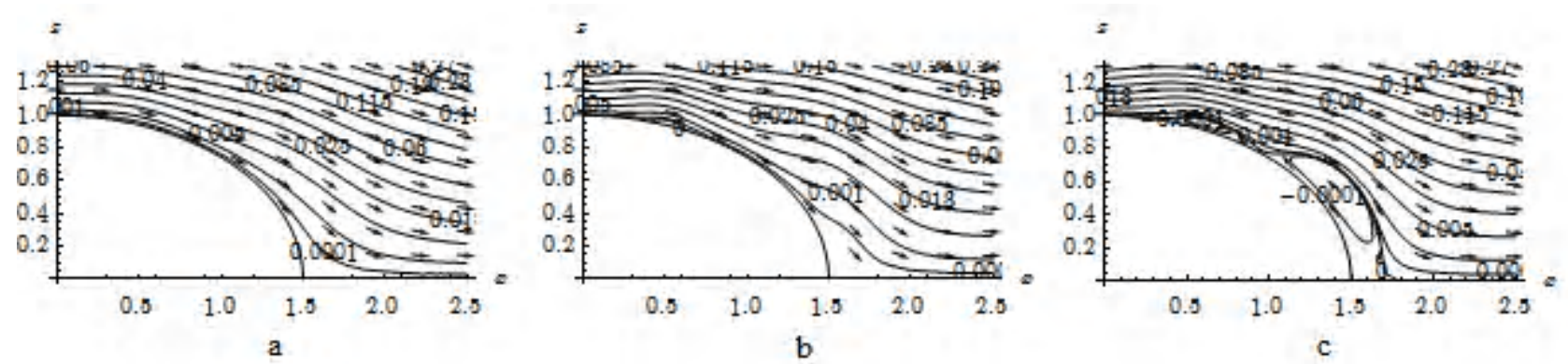

Figure 4 - Detailed pictures of streamlined contours and vector velocity field behind the ellipsoid:

$$
\mathrm{a}-\operatorname{Re}=10, \mathrm{~b}-\operatorname{Re}=30, \mathrm{c}-\operatorname{Re}=50
$$
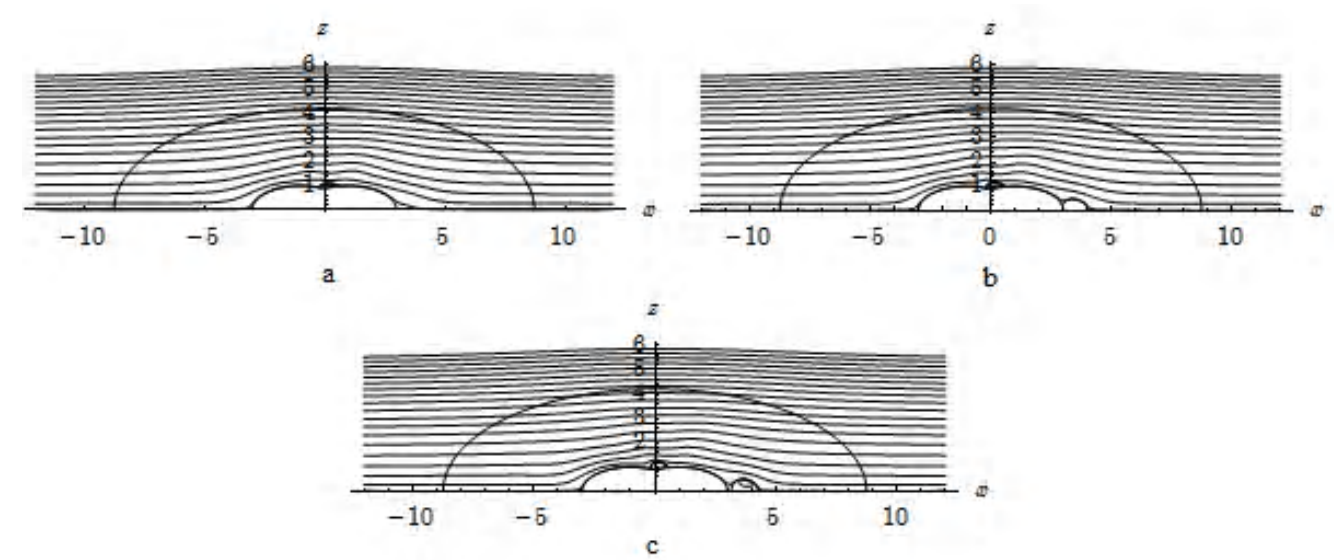

Figure 5 - Streamlined contours of obtained approximate solution for flow past two articulated ellipsoids:

$$
\mathrm{a}-\operatorname{Re}=5, \mathrm{~b}-\operatorname{Re}=10, \mathrm{c}-\operatorname{Re}=20
$$



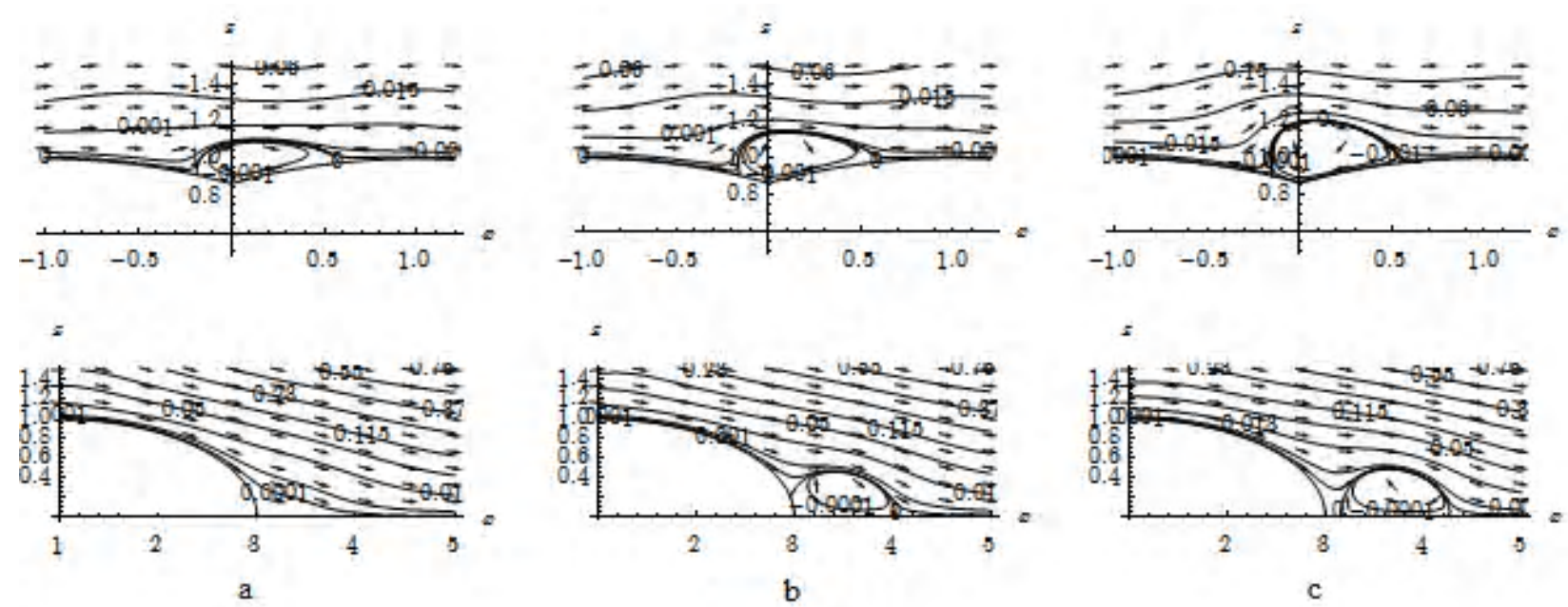

Figure 6 - Detailed pictures of streamlined contours and vector velocity field behind ellipsoids and in the hollow between them:

$$
\mathrm{a}-\operatorname{Re}=5, \mathrm{~b}-\operatorname{Re}=10, \mathrm{c}-\operatorname{Re}=20
$$

\section{DISCUSSION}

For small Reynolds numbers, the flow is symmetrical, without the formation of a detachment zone in the aft domain of the body. With an increase in the Reynolds number the flow pattern changes: the secondary vortices appear behind the body and their size and intensity increase.

In the task of flow past a sphere, it is found that the secondary vortices behind the body appear with an increase in the Reynolds number up to $\approx 20-25$. For the task of flow past an ellipsoid of rotation with the ratio of the semiaxes of an ellipsoid $\frac{a}{b} \geq 2$, the secondary vortices behind the body do not appear independently of the Reynolds number, but appear with a decrease in the ratio of the semiaxes. For two articulated ellipsoids, a computational experiment showed that as the Reynolds number increases up to $\approx 10$, vortices appear behind the body and in the hollow at the junction of the ellipsoids.

The obtained results correlate with the known results of physical experiments [18] and the results obtained by other authors $[19,20]$, which indicates the effectiveness of the developed numerical method.

\section{CONCLUSIONS}

A new numerical method for the calculating the external flows of viscous incompressible fluid is proposed. The proposed method is based on the joint application of the $R$ functions method, successive approximations and Galerkin method. The algorithm of the method does not change when the geometry of the domain is changed, and the structure of the solution accurately takes into account both the boundary conditions on the boundary of the streamlined body and the condition at infinity. It is experimentally established that the iterative process begins to diverge at Reynolds numbers $\operatorname{Re}>10$. In this case, to approximate the undetermined components of the structure of the solution of the nonlinear stationary problem of flow past a body of revolution by a viscous incompressible fluid in a spherical coordinate system the nonlinear Galerkin method was applied. For various Reynolds numbers, the stationary problem of flow past a body of rotation in a spherical coordinate system for a sphere, ellipsoid, and two articulated ellipsoids has been solved numerically. For each body Reynolds numbers, at which secondary vortices arise behind the body, are defined.

\section{ACKNOWLEDGMENTS}

The work was carried out at the department of Applied Mathematics at Kharkiv National University of Radio Electronics and department of Advanced Mathematics at O. M. Beketov National University of Urban Economy in Kharkiv within the framework of collaborative scientific research conducted by the departments.

\section{REFERENCES}

1. Лойцянский Л. Г. Механика жидкости и газа / Л. Г. Лойцянский. - М. : Дрофа, 2003. - 840 с.

2. Химическая гидродинамика : справочное пособие / [А. М. Кутепов, А. Д. Полянин, 3. Д. Запрянов, А. В. Вязьмин, Д. А. Казенин]. - М. : Квантум, 1996. - 336 с.

3. Рвачев В. Л. Теория $R$-функций и некоторые ее приложения / В. Л. Рвачев. - К.: Наук. думка, 1982. - 552 с.

4. Shapiro V. Semi-analytic geometry with $R$-functions / V. Shapiro // Acta Numerica. - 2007. - V. 16. - P. 239-303.

5. Колосова С. В. Применение проекционных методов и метода $R$-функций к решению краевых задач в бесконечных областях: дисс. ... к. ф.-м. н.: 01.01.07 - Вычислительная математика / С. В. Колосова. - Харьков: ХИРЭ, 1972. - 85 с.

6. Колосова С. В. Применение метода $R$-функций к расчету плоских течений вязкой жидкости / С. В. Колосова, М. В. Сидоров // Вісник Харківського національного університету. Сер. Прикл. матем. і мех. - 2003. - № 602. - С. 61-67.

7. Суворова И. Г. Компьютерное моделирование осесимметричных течений жидкости в каналах сложной формы / И. Г. Суворова // Вестник национального технического университета «ХПИ». - 2004. - № 31. - С. 141-148.

8. Тевяшев А. Д. Об одном подходе к математическому моделированию плоских стационарных течений вязкой несжимаемой жидкости в конечных односвязных областях / А. Д. Тевяшев, Н. В. Гибкина, М. В. Сидоров // Радиоэлектроника и информатика. - 2007. - № 2 (37). - С. 50-57.

9. Максименко-Шейко К. В. Математическое моделирование теплообмена при движении жидкости по каналам с винтовым типом симметрии методом $R$-функций / К. В. Максименко-Шейко // Доповіді Національної академії наук України. - 2005. № 9 . - C. 41-46. 
10. Artyukh A. Mathematical modeling and numerical analysis of nonstationary plane-parallel flows of viscous incompressible fluid by $R$-functions and Galerkin method / A. Artyukh, M. Sidorov // Econtechmod. - 2014. - Vol. 3, No 3. - P. 3-11.

11. Ламтюгова С. Н. Математическое моделирование линеаризованных задач обтекания в сферической и цилиндрической системах координат / С. Н. Ламтюгова // Вісник Запорізького національного університету. Сер. Фізико-математичні науки. 2012. - № 1. - C. 112-122.

12. Ламтюгова С. М. Застосування методу $R$-функцій до розрахунку зовнішніх повільних течій в'язкої рідини / С. М. Ламтюгова, М. В. Сидоров // Відбір і обробка інформації. - 2012. № 36 (112). - C. 56-62.

13. Lamtyugova S. N. Numerical analysis of the external slow flows of a viscous fluid using the $R$-function method / S. N. Lamtyugova, M. V. Sidorov // Journal of Engineering Mathematics. - 2015. Vol. 91, No. 1. - P. 59-79. DOI:10.1007/s10665-014-9746-x

14. Колосова С. В. Применение итерационных методов к решению внешних задач гидродинамики / С. В. Колосова, С. Н. Ламтюгова, М. В. Сидоров // Радиоэлектроника и информатика. - 2012. - № 3. - С. 13-17.
15. Ламтюгова С. Н. Применение итерационных методов к расчету обтекания тел стационарным потоком вязкой жидкости / С. Н. Ламтюгова // Радиоэлектроника и информатика. - 2015. № 2. - C. 49-56.

16. Колосова С. В. Об одном методе численного анализа вязких течений, усложненных массообменом (задача обтекания) / С. В. Колосова, С. Н. Ламтюгова, М. В. Сидоров // Радиоэлектроника и информатика. - 2014. - № 1 (64). - С. 25-30.

17. Полянин А. Д. Справочник по линейным уравнениям математической физики / А. Д. Полянин. - М. : Физматлит, 2001. $576 \mathrm{c}$.

18. Ван-Дайк М. Альбом течений жидкости и газа / М. Ван-Дайк. М. : Мир, 1986. - 184 c.

19. Batchelor G. K. An introduction to fluid dynamics G. K. Batchelor. - Cambridge : Cambridge University Press, 1967. $615 \mathrm{p}$.

20. Taamneh Y. CFD Simulations of Drag and Separation Flow Around Ellipsoids / Y. Taamneh // Jordan Journal of Mechanical and Industrial Engineering. - 2011. - Vol. 5, No. 2. - P. 129-132.

Article was submitted 16.07.2017. After revision 05.09.2017.

Ламтюгова С. М. ${ }^{1}$, Сидоров М. В. ${ }^{2}$, Ситникова Ю. В. ${ }^{3}$

${ }^{1}$ Канд. фіз.-мат. наук, асистент кафедри вищої математики Харківського національного університету міського господарства імені О. М. Бекетова, Харків, Україна

${ }^{2}$ Канд. фіз.-мат. наук, доцент, доцент кафедри прикладної математики Харківського національного університету радіоелектроніки, Харків, Україна

${ }^{3}$ Канд. пед. наук, доцент кафедри вищої математики Харківського національного університету міського господарства імені О. М. Бекетова, Харків, Україна

МЕТОД ЧИСЕЛЬНОГО АНАЛІЗУ ЗАДАЧІ ОБТІКАННЯ ТІЛ ОБЕРТАННЯ СТАЦІОНАРНИМ ПОТОКОМ В'ЯЗКОӤ РІДИНИ

Актуальність. У статті розглядається нелінійна стаціонарна задача обтікання тіла обертання в'язкою нестисливою рідиною.

Мета роботи - розробка нового методу чисельного аналізу стаціонарних задач обтікання тіл обертання в'язкою нестисливою рідиною.

Метод. Математичною моделлю розглядуваного процесу служить нелінійна крайова задача для функції течії, отримана переходом від системи рівнянь Нав'є-Стокса до одного нелінійного рівняння четвертого порядку. Особливістю постановки задачі обтікання є те, що крайова задача розглядається в нескінченній області і для функції течії ставляться як крайові умови на межі тіла, що обтікається, так і умова на нескінченності. За допомогою структурного методу (методу $R$-функцій) будується структура розв'язку задачі, яка точно задовольняє всі крайові умови задачі, в тому числі гарантує потрібну поведінку функції течії на нескінченності. Для апроксимації невизначених компонент структури пропонується два підходи. Перший підхід заснований на використанні методу послідовних наближень, який дозволяє звести розв'язування вихідної нелінійної задачі до розв'язування послідовності лінійних крайових задач. На кожному кроці ітераційного процесу ці лінійні задачі розв'язуються методом Бубнова-Гальоркіна. Другий підхід до апроксимації невизначених компонент структури заснований на застосуванні нелінійного методу Гальоркіна і його пропонується використовувати в разі розбіжності послідовних наближень. У цьому випадку розв'язування вихідної нелінійної задачі зводиться до розв'язування системи нелінійних алгебраїчних рівнянь.

Результати. Обчислювальний експеримент проведений для задачі обтікання сфери, еліпсоїда обертання і двох з’єднаних еліпсоїдів для різних чисел Рейнольдса.

Висновки. Проведені експерименти підтвердили працездатність запропонованого методу чисельного аналізу стаціонарних задач обтікання тіл обертання в'язкою нестисливою рідиною. Перспективи подальших досліджень можуть полягати у використанні розробленого методу при реалізації полудіскретних і проекційних методів розв'язання нестаціонарних задач.

Ключові слова: задача обтікання, стаціонарна течія, в'язка рідина, функція течії, метод $R$-функцій, метод послідовних наближень, метод Гальоркіна.

Ламтюгова С. Н. ${ }^{1}$, Сидоров М. В. ${ }^{2}$, Ситникова Ю. В. ${ }^{3}$

${ }^{1}$ Канд. физ.-мат. наук, ассистент кафедры высшей математики Харьковского национального университета городского хозяйства имени А. Н. Бекетова, Харьков, Украина

${ }^{2}$ Канд. физ.-мат. наук, доцент, доцент кафедры прикладной математики Харьковского национального университета радиоэлектроники, Харьков, Украина

${ }^{3}$ Канд. пед. наук, доцент кафедры высшей математики Харьковского национального университета городского хозяйства имени А. Н. Бекетова, Харьков, Украина

МЕТОД ЧИСЛЕННОГО АНАЛИЗА ЗАДАЧИ ОБТЕКАНИЯ ТЕЛ ВРАЩЕНИЯ СТАЦИОНАРНЫМ ПОТОКОМ ВЯЗКОЙ жидкости

Актуальность. В статье рассматривается нелинейная стационарная задача обтекания тела вращения вязкой несжимаемой жидкостью.

Цель работы - разработка нового метода численного анализа стационарных задач обтекания тел вращения вязкой несжимаемой жидкостью.

Метод. Математической моделью рассматриваемого процесса служит нелинейная краевая задача для функции тока, полученная переходом от системы уравнений Навье-Стокса к одному нелинейному уравнению четвертого порядка. Особенностью постановки 
задачи обтекания является то, что краевая задача рассматривается в бесконечной области и для функции тока ставятся как краевые условия на границе обтекаемого тела, так и условие на бесконечности. С помощью структурного метода (метода $R$-функций) строится структура решения задачи, которая точно удовлетворяет всем краевым условиям задачи, в том числе гарантирует нужное поведение функции тока на бесконечности. Для аппроксимации неопределенных компонент структуры предлагается два подхода. Первый подход основан на использовании метода последовательных приближений, который позволяет свести решение исходной нелинейной задачи к решению последовательности линейных краевых задач. На каждом шаге итерационного процесса эти линейные задачи решаются методом Бубнова-Галеркина. Второй подход к аппроксимации неопределенных компонент структуры основан на применении нелинейного метода Галеркина и его предлагается использовать в случае расходимости последовательных приближений. В этом случае решение исходной нелинейной задачи сводится к решению системы нелинейных алгебраических уравнений.

Результаты. Вычислительный эксперимент проведен для задачи обтекания сферы, эллипсоида вращения и двух сочлененных эллипсоидов для различных чисел Рейнольдса.

Выводы. Проведенные эксперименты подтвердили работоспособность предложенного метода численного анализа стационарных задач обтекания тел вращения вязкой несжимаемой жидкостью. Перспективы дальнейших исследований могут заключаться в использовании разработанного метода при реализации полудискретных и проекционных методов решения нестационарных задач.

Ключевые слова: задача обтекания, стационарное течение, вязкая жидкость, функция тока, метод $R$-функций, метод последовательных приближений, метод Галеркина.

\section{REFERENCES}

1. Lojcjanskij L. G. Mehanika zhidkosti i gaza. Moscow, Drofa, $2003,840 \mathrm{p}$.

2. Kutepov A. M., Poljanin A. D., Zaprjanov Z. D., Vjaz’min A. V., Kazenin D. A. Himicheskaja gidrodinamika: spravochnoe posobie. Moscow, Kvantum, 1996, 336 p.

3. Rvachev V. L. Teorija $R$-funkcij i nekotorye ee prilozhenija. Kiev, Nauk. dumka, 1982, $552 \mathrm{p}$.

4. Shapiro V. Semi-analytic geometry with $R$-functions, Acta Numerica, 2007, V. 16, pp. 239-303.

5. Kolosova S. V. Primenenie proekcionnyh metodov i metoda $R$ funkcij $\mathrm{k}$ resheniju kraevyh zadach $\mathrm{v}$ beskonechnyh oblastjah: diss. ... k. f.-m. n.: 01.01.07. Vychislitel'naja matematika. Har'kov, HIRJe, 1972, 85 p.

6. Kolosova S. V., Sidorov M. V. Primenenie metoda $R$-funkcij k raschetu ploskih techenij vjazkoj zhidkosti, Visnyk Harkivs 'kogo nacional'nogo universytetu. Ser. Prykl. matem. i meh., 2003, No. 602, pp. 61-67.

7. Suvorova I. G. Komp'juternoe modelirovanie osesimmetrichnyh techenij zhidkosti v kanalah slozhnoj formy, Vestnik nacional'nogo tehnicheskogo universiteta «HPI», 2004, No. 31, pp. 141-148.

8. Tevjashev A. D., Gibkina N. V., Sidorov M. V. Ob odnom podhode $\mathrm{k}$ matematicheskomu modelirovaniju ploskih stacionarnyh techenij vjazkoj neszhimaemoj zhidkosti v konechnyh odnosvjaznyh oblastjah, Radiojelektronika i informatika, 2007, No. 2 (37), pp. 50-57.

9. Maksimenko-Shejko K. V. Matematicheskoe modelirovanie teploobmena pri dvizhenii zhidkosti po kanalam s vintovym tipom simmetrii metodom $R$-funkcij, Dopovidi Nacional'noi' akademii' nauk Ukrai'ny, 2005, No. 9, pp. 41-46.

10. Artyukh A., Sidorov M. Mathematical modeling and numerical analysis of nonstationary plane-parallel flows of viscous incompressible fluid by $R$-functions and Galerkin method, Econtechmod, 2014, Vol. 3, No 3, pp. 3-11.

11.Lamtyugova S. N. Matematicheskoe modelirovanie linearizovannyh zadach obtekanija $\mathrm{v}$ sfericheskoj i cilindricheskoj sistemah koordinat, Visnyk Zaporiz'kogo nacional'nogo universytetu. Ser. Fizyko-matematychni nauky, 2012, No. 1, pp. 112-122.

12. Lamtjugova S. M., Sidorov M. V. Zastosuvannja metodu $R$-funkcij do rozrahunku zovnishnih povil'nih techij v'jazkoï ridini, Vidbir i obrobka informaciï, 2012, No. 36 (112), pp. 56-62.

13. Lamtyugova S. N., Sidorov M. V. Numerical analysis of the external slow flows of a viscous fluid using the $R$-function method, Journal of Engineering Mathematics, 2015, Vol. 91, No. 1, pp. 59-79. DOI: 10.1007/s10665-014-9746-x

14. Kolosova S. V., Lamtyugova S. N., Sidorov M. V. Primenenie iteracionnyh metodov $\mathrm{k}$ resheniju vneshnih zadach gidrodinamiki, Radiojelektronika i informatika, 2012, No. 3, pp. 13-17.

15. Lamtyugova S. N. Primenenie iteracionnyh metodov $\mathrm{k}$ raschetu obtekanija tel stacionarnym potokom vjazkoj zhidkosti, Radiojelektronika i informatika, 2015, No. 2, pp. 49-56.

16. Kolosova S. V., Lamtyugova S. N., Sidorov M. V. Ob odnom metode chislennogo analiza vjazkih techenij, uslozhnennyh massoobmenom (zadacha obtekanija), Radiojelektronika $i$ informatika, 2014, No. 1 (64), pp. 25-30.

17.Poljanin A. D. Spravochnik po linejnym uravnenijam matematicheskoj fiziki. Moscow, Fizmatlit, 2001, 576 p.

18. Van-Dajk M. Al'bom techenij zhidkosti i gaza. Moscow, Mir, 1986, $184 \mathrm{p}$.

19. Batchelor G. K An introduction to fluid dynamics, Cambridge: Cambridge University Press, 1967, 615 p.

20. Taamneh Y. CFD Simulations of Drag and Separation Flow Around Ellipsoids, Jordan Journal of Mechanical and Industrial Engineering, 2011, Vol. 5, No. 2, pp. 129-132. 